\title{
PERBAIKAN DAYA HASIL DAN KETAHANAN KACANG HIJAU TERHADAP HAMA KUMBANG BUBUK MELALUI PERSILANGAN ANTAR SPESIES
}

\author{
Lestari Ujianto, Nur Basuki, Kuswanto, Astanto Kasno \\ ${ }^{*}$ Fakultas Pertanian Universitas Mataram, Jl. Majapahit 62 Mataram NTB, \\ ujianto_l@yahoo.com \\ ${ }^{* *}$, Universitas Brawijaya Malang, ${ }^{* * *}$ Balitkabi Kendalpayak Malang
}

\begin{abstract}
ABSTRAK: Persilangan antar spesies kacang hijau dan kacang uci telah berhasil dilakukan. Kacang uci memiliki keunggulan yaitu tahan terhadap hama kumbang bubuk dan jumlah polongnya banyak. Dengan persilangan antar spesies ini dapat memperbaiki daya hasil dan ketahanan kacang hijau terhadap hama kumbang bubuk. Penelitian ini terdiri atas 4 tahap kegiatan yaitu: 1) persilangan antar spesies kacang hijau dengan kacang uci, 2). evaluasi dan seleksi beberapa populasi keturunan persilangan (F1) berdasarkan daya hasil dan ketahanan terhadap hama kumbang bubuk. Evaluasi dilakukan terhadap komponen hasil dan hasil, dan ketahanan terhadap kumbang bubuk menggunakan metode Chiang dan Talekar. Hasil dari penelitian ini adalah bahwa : 1). Terjadi perbaikan daya hasil dan ketahanan terhadap hama kumbang bubuk pada populasi hasil persilangan antara kacang hijau dan kacang uci. 2). Tingkat daya silang antara varietas yang satu dengan yang lainnya berbeda. Varietas Manyar dan Sampeong memiliki daya silang terhadap kacang uci dibandingkan dengan varietas Vima dan Merak, 3). Karakteristik populasi keturunan hasil persilangan berada diantara kedua tetuanya.
\end{abstract}

Kata kunci: persilangan antar spesies, kacang hijau, daya hasil, kumbang bubuk

\section{PENDAHULUAN}

$$
\text { Kacang hijau (Vigna }
$$

radiata (L.) Wilczek) merupakan

salah satu tanaman kacang-kacangan

utama di Indosesia sehingga perlu

mendapat perhatian. Tanaman ini

memiliki beberapa keunggulan antara lain nilai gizi dan kandungan proteinnya yang tinggi dan umur panennya relatif genjah. Kandungan proteinnya berkisar antara $20-30$ $\%$, daya cernanya lebih tinggi dan gas dalam perut lebih rendah dibandingkan tanaman lainnya sehingga cocok untuk bahan 
makanan segala umur mulai bayi sampai orang lanjut usia (Arshad et al., 2009; Fery, 2002). Disamping keunggulannya, kacang hijau memiliki kelemahan yaitu hasilnya masih rendah 1,072 ton/ha (Badan Pusat Statistik, 2009) dan rentan terhadap hama kumbang bubuk. Oleh karena itu perlu upaya-upaya untuk meningkatkan hasil dan ketahanan terhadap hama penting melalui program pemuliaan tanaman.

$$
\text { Dalam rangka perakitan }
$$

varietas unggul baru kacang hijau yang memiliki daya hasil tinggi dan tahan terhadap hama kumbang bubuk, pemulia perlu sumber gen yang mengendalikan sifat tersebut untuk digunakan sebagai tetua. Kacang uci (Vigna umbellata (Thunb) Ohwi dan Ohashi) memiliki keunggulan yang tidak dimiliki kacang hijau yaitu memiliki jumlah polong per tanaman yang banyak dan tahan terhadap kumbang bubuk. Jumlah polong merupakan komponen utama hasil, dengan perbaikan jumlah polong akan memperbaiki hasil selama komponen lain dapat dipertahankan. Oleh karena itu kacang uci ini cocok digunakan sebagai tetua donor untuk merakit varietas unggul kacang hijau yang berdaya hasil tinggi dan tahan terhadap kumbang bubuk. Untuk itu persilangan antar spesies kacang hijau dan kacang uci ini perlu dilakukan untuk menggabungkan keunggulan dari kedua tanaman dalam keturunannya disamping untuk memperbesar keragaman genetik terhadap sifat yang diinginkan (Thiyagu, Jayaman, dan Nadarajan, 2008; Somta, Talekar dan Srinives, 2006).

Salah satu hal yang sangat penting dalam program pemuliaan tanaman yaitu adanya keragaman genetik terhadap sifat yang akan diperbaiki, karena tanpa adanya keragaman maka sulit didapatkan kemajuan genetiknya. Oleh karena 


\begin{tabular}{|c|c|}
\hline & caranya yaitu \\
\hline hibridisasi baik dalam spesies yang & Jumlah polong \\
\hline sama maupun antar spesies yang & komponen utama daya hasil kacang \\
\hline $\begin{array}{l}\text { berbeda asalkan masing-masing } \\
\text { tetuanya memiliki keunggulan }\end{array}$ & $\begin{array}{l}\text { hijau dan memiliki korelasi } \\
\text { genotipik yang positif nyata dengan }\end{array}$ \\
\hline karakter yang diinginkan. Untuk & hasil serta memiliki ragama aditif \\
\hline merakit varietas unggul kacang & yang tinggi. Dengan demikian \\
\hline hijau yang berdaya hasil tinggi dan & diharapkan bahwa dengan \\
\hline tahan terhadap hama kumbang & perbaikan jumlah polong akan \\
\hline bubuk maka perlu adanya & memperbaiki daya hasil. \\
\hline keragaman genetik terhadap sifat & karena itu untuk menggabungkan \\
\hline tersebut. Kacang uci yang masih & keunggulan sifat dari kacang hijau \\
\hline satu genus dan memiliki jumlah & dan kacang uci perlu dilakukan \\
\hline kromosom yang sama dengan & persilangan antar spesies. \\
\hline kacang hijau yaitu $2 \mathrm{n}=2 \mathrm{x}=22$ & informasi- \\
\hline memiki potensi untuk menjadi & informasi ini pemulia dapat \\
\hline sumber gen dalam perbaikan & mengetahui karakteristik populasi \\
\hline karakter hasil dan ketahanan & yang terbentuk akibat persilangan \\
\hline terhadap hama kumbang bubuk. & antar spesies kacang hijau dengan \\
\hline Kacang uci memiliki karakteristik & kacang uci. Dengan demikian \\
\hline jumlah polongnya banyak, relatif & pemulia dapat mengambil langkah- \\
\hline han terhadap hampir semua hama & kegiatan \\
\hline dan beberapa penyakit, toleran & pemuliaan berikutnya dalam rangka \\
\hline & as \\
\hline
\end{tabular}


berdaya hasil tinggi dan tahan terhadap hama kumbang bubuk. Tujuan dari penelitian ini adalah untuk memperbaiki daya hasil dan ketahanan kacang hijau terhadap hama kumbang bubuk melalui persilangan antar spesies dengan kacang uci.

\section{METODE PENELITIAN}

Penelitian ini terdiri atas
dua tahap kegiatan yaitu: 1)
persilangan antar spesies kacang
hijau yang memiliki hasil tinggi
tetapi rentan terhadap kumbang
bubuk (P1) dengan kacang uci (P2)
yang memiliki ketahanan terhadap
hama kumbang bubuk dan jumlah
polong yang banyak sebagai
komponen utama hasil untuk
membentuk F1 yang memiliki sifat
gabungan dari kedua tetua, 2).
Evaluasi beberapa seri persilangan
dan seleksi beberapa populasi
F1Evaluasi dan seleksi untuk
memilih individu ataupun populasi
yang superior didasarkan pada

karakter yang berhubungan dengan daya hasil dan ketahanan terhadap kumbang bubuk. Kreteria seleksi yang digunakan meliputi jumlah polong per tanaman, jumlah biji per polong, berat biji kering per tanaman, jumlah imago, dan tingkat kerusakan akibat serangan kumbang bubuk.

Percobaan dilakukan di kebun hibridisasi dan evaluasi di Fakultas Pertanian Universitas Mataram mulai bulan Nopember 2009 hingga Juni 2010. Persilangan dalam rangka membentuk populasi F1 mengacu metode yang dilakukan oleh IITA Research Guide 42 Hand Crossing of Cowpea (Myers, 1996). Emaskulasi dilakukan dengan cara memotong 1/3 bagian bunga betina yang diperkirakan besoknya akan mekar. Persilangan dilakukan antara varietas unggul kacang hijau terpilih yang berdaya hasil tinggi walaupun rentan disilangkan dengan genotip kacang uci terpilih yang tahan 
kumbang bubuk dan dilakukan juga resiproknya.

Evaluasi daya hasil dan ketahanan terhadap kumbang bubuk pada populasi F1 menggunakan rancangan acak kelompok lengkap dan masingmasing perlakuan diulang 4 kali. Perlakuan terdiri atas 8 seri persilangan yaitu persilangan antara 4 varietas kacang hijau (Vima-1, Merak, Manyar, dan Sampeyong) dengan 2 genotip kacang uci (kacang uci berbiji merah dan berbiji kuning) ditambah dengan tetuanya, sehingga totalnya adalah 56 unit percobaan. Evaluasi daya hasil populasi F1 terdiri atas beberapa kegiatan yaitu persiapan benih, penyiapan media tanam, penanaman, pemeliharaan, dan pemanenan.

Data hasil pengamatan
dianalisis tingkat
persilangan, analisis keragaman dan uji lanjut DMRT dan analisis pendugaan nilai heritabilitas, serta evaluasi ketahanan terhadap hama kumbang bubuk menggunakan metode Chiang dan Talekar (1980).

\section{HASIL DAN PEMBAHASAN}

Hasil dari kegiatan penelitian tahap pertama mengenai hibridisasi antara 4 varietas unggul kacang hijau yang memiliki karakteristik berbeda dengan 2 genotip kacang uci yang bijinya berwarna merah dan kuning didapatkan 8 keturunan pertama. Banyaknya benih tiap hasil keturunan berbeda-beda karena tingkat keberhasilan hibridisasinya juga berbeda-beda. Tingkat keberhasilan persilangannya berkisar antara $44 \%$ hingga $65 \%$. Varietas Manyar dan Sampeong 
menunjukkan tingkat keberhasilan

yang cukup tinggi yaitu lebih dari 63

$\%$ baik dengan kacang uci berbiji

kuning maupun merah. Hal ini

menunjukkan bahwa kedua varietas

ini menunjukkan daya silang yang

cukup tinggi dibandingkan dengan

varietas Vima dan Merak.

Keberhasilan persilangan ini

dipengaruhi baik oleh faktor genetik

maupun lingkungan. Varietas-

varietas tertentu memiliki tingkat

keguguran bunga yang rendah dan

daya reseptif kepala putik terhadap

tepung sari yang tinggi

menyebabkan tingkat keberhasilan

persilangan lebih tinggi.Tingkat

keberhasilan ini juga dipengaruhi

karena kedua tanaman ini spesiesnya

berbeda sehingga sering terjadi

kegagalan dalam proses

pembentukan polongnya. Menurut

Hadley dan Openshaw (1980), faktor

lingkungan yang sangat berpengaruh

terhadap keberhasilan persilangan

adalah curah hujan, penyinaran

matahari, temperatur dan kelembaban udara. Disamping itu faktor ketrampilan pemulia dalam memahami biologi bunga dan ketrampilan dalam emaskulasi maupun polinasi juga berpengaruh terhadap tingkat keberhasilan persilangan.

Pada pengujian ketahanan terhadap hama kumbang bubuk menunjukkan bahwa keturunan hasil persilangan antar spesies menunjukkan tingkat ketahanan diantara kedua tetua. Tanaman kacang hijau memiliki tingkat ketahanan yang rendah yaitu antara rentan hingga agak rentan, sedangkan kacang uci menunjukkan tingkat ketahanan yang cukup tinggi. Berdasarkan hasil perhitungan kategori ketahanan menurut Chiang dan Talekar, dikategorikan sangat tahan, tahan, agak tahan, rentan, dan sangat rentan jika tingkat kerusakan biji berturut-turut sebesar < 11,1 \%, $11,1-36,8 \%, 36,9-62,6 \%, 62,7$ $88,29 \%$, dan $>88,29 \%$ tahan Pada Tabel 1 terlihat bahwa tingkat 
ketahanan keturunan persilangan antar spesies terletak diantara ketahananan kedua tetuanya.

Tingkat ketahanan populasi

keturunan persilangan antar spesies tertinggi dicapai oleh populasi keturunan persilangan kacang hijau varietas Manyar dengan kacang uci yang berbiji merah dengan tingkat kerusakan biji sebesar $21 \%$ dan tergolong tahan.

Tabel 1. Tingkat Ketahanan Keturunan Hasil Persilangan Kacang Hijau dan Kacang Uci terhadap Hama Kumbang Bubuk

\begin{tabular}{|c|c|c|c|c|c|}
\hline No. & $\begin{array}{l}\text { Populasi yang } \\
\text { Diuji }\end{array}$ & $\begin{array}{l}\text { Jumlah } \\
\text { Telur }\end{array}$ & $\begin{array}{l}\text { Jumlah } \\
\text { Biji Rusak }\end{array}$ & $\begin{array}{l}\text { Tingkat } \\
\text { Kerusakan } \\
\text { (\%) }\end{array}$ & $\begin{array}{l}\text { Ketahanan } \\
\text { Populasi } \\
\text { Keturunan }\end{array}$ \\
\hline 1 & MANYAR & 253 & 135 & 67.5 & Rentan \\
\hline 2 & $\begin{array}{l}\text { MANYAR X } \\
\text { RBK }\end{array}$ & 213 & 45 & 22.5 & Tahan \\
\hline 3 & $\begin{array}{l}\text { MANYAR X } \\
\text { RBM }\end{array}$ & 221 & 42 & 21.0 & Tahan \\
\hline 4 & MERAK & 324 & 168 & 84.0 & Rentan \\
\hline 5 & MERAK X RBK & 317 & 56 & 28.0 & Tahan \\
\hline 6 & MERAK X RBM & 302 & 53 & 26.5 & Tahan \\
\hline 7 & SAMPEONG & 271 & 143 & 71.5 & Rentan \\
\hline 8 & $\begin{array}{l}\text { SAMPEONG X } \\
\text { RBK }\end{array}$ & 256 & 48 & 24.0 & Tahan \\
\hline 9 & $\begin{array}{l}\text { SAMPEONG X } \\
\text { RBM }\end{array}$ & 247 & 51 & 25.5 & Tahan \\
\hline 10 & VIMA & 375 & 148 & 74.0 & Rentan \\
\hline 11 & VIMA X RBK & 344 & 56 & 28.0 & Tahan \\
\hline 12 & VIMA X RBM & 321 & 59 & 29.5 & Tahan \\
\hline 13 & RBK & 73 & 17 & 8.5 & $\begin{array}{l}\text { Sangat } \\
\text { Tahan }\end{array}$ \\
\hline
\end{tabular}




\begin{tabular}{|c|c|c|c|c|}
\hline 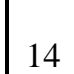 & RBM & 78 & 11 & 5.5 \\
\hline
\end{tabular}

Keterangan: $\mathrm{RBM}=$ kacang uci berbiji merah, dan RBK = kacang uci berbiji kuning

Tingkat ketahanan terhadap yang mendorong berkembangnya

kumbang bubuk antara keturunan hama ini yaitu jika di atas $65 \%$.

persilangan yang satu dengan yang

lainnya berbeda. Hal ini disebabkan

karena tingkat ketahanan dari kedua

tetuanya juga berbeda. Tingkat

ketahanan terhadap kumbang bubuk

disamping dipengaruhi oleh faktor

genetik juga dipengaruhi faktor

lingkungan. Menurut Singh et al.

(1985), faktor lingkungan yang

sangat berpengaruh terhadap tingkat

ketahanan adalah kadar air benih,

temperatur dan kelembaban udara.

Pada kadar air tertentu hama

kumbang bubuk mudah menyerang

yaitu pada kadar air di atas $10 \%$,

sedangkan pada kadar air di bawah

10 hama ini jarang atau sulit

menyerang. Kondisi temperatur yang

optimum untuk pertumbuhan dan

Menurut Talekar (1997),

tanaman yang rentan dan kondisi

lingkungan yang mendukung akan

menyebabkan terserangnya biji-biji

tanaman ini dari hama kumbang

bubuk, sebaliknya tanaman yang

tahan dan kondisi lingkungan yang

tidak mendukung akan menyulitkan

hama ini menyerang dan

berkembang. Dari hasil penelitian

ini terdapat perubahan tingkat

ketahanan populasi hasil persilangan

antar spesies terhadap hama

kumbang bubuk. Tingkat ketahanan

populasi keturunan lebih tinggi

dibandingkan tetua kacang hijau

tetapi masih lebih rendah

dibandingkan kacang uci.

perkembangan hama ini adalah

antara $26-31{ }^{0} \mathrm{C}$. Kelembaban 
Tabel 2. Rata-rata dan Uji Jarak Berganda Duncan untuk Hasil dan Komponen Hasil

\begin{tabular}{|c|c|c|c|c|c|c|c|c|c|c|c|}
\hline \multirow{2}{*}{$\frac{\text { No }}{1}$} & Genotip & \multicolumn{2}{|c|}{\begin{tabular}{|l|} 
Tinggi \\
Tanaman \\
\end{tabular}} & \multicolumn{2}{|c|}{$\begin{array}{l}\text { Jumlah } \\
\text { Cabang }\end{array}$} & \multicolumn{2}{|c|}{$\begin{array}{l}\text { Jumlah Biji p } \\
\text { Polong }\end{array}$} & \multicolumn{2}{|c|}{$\begin{array}{l}\text { Jumlah } \\
\text { Polong }\end{array}$} & \multicolumn{2}{|c|}{$\begin{array}{l}\text { Berat Biji } \\
\text { Tanaman }\end{array}$} \\
\hline & $\begin{array}{l}\text { MANYAR } \\
\text { MANYAR }\end{array}$ & 66.8 & cde & 2.3 & $a b$ & 12.2 & & 27.5 & abc & 8.9 & \\
\hline 2 & $\begin{array}{l}\text { RBK } \\
\text { MANYAR }\end{array}$ & 70.8 & de & 2.5 & $\mathrm{ab}$ & 12.7 & c & 38.8 & c & 13.0 & $\mathrm{a}$ \\
\hline 3 & RBM & 72.8 & def & 2.8 & $a b$ & 12.5 & c & 36.3 & bc & 13.6 & $\mathrm{a}$ \\
\hline 4 & $\begin{array}{l}\text { MERAK } \\
\text { MERAK }\end{array}$ & 48.5 & $a b$ & 2.0 & $\mathrm{ab}$ & 10.4 & a & 21.8 & $a b$ & 7.0 & $\mathrm{a}$ \\
\hline 5 & $\begin{array}{l}\text { RBK } \\
\text { MERAK }\end{array}$ & 60.0 & bcd & 2.3 & $\mathrm{ab}$ & 10.9 & $a b c$ & 26.8 & abc & 11.1 & $\mathrm{a}$ \\
\hline 6 & RBM & 55.5 & $a b c$ & 2.0 & $a b$ & 11.2 & abc & 25.5 & abc & 8.2 & $\mathrm{a}$ \\
\hline 7 & $\begin{array}{l}\text { SAMPEONG } \\
\text { SAMPEONG }\end{array}$ & 68.0 & cde & 2.5 & $a b$ & 12.2 & bc & 25.5 & abc & 7.0 & $\mathrm{a}$ \\
\hline 8 & & 75.0 & ef & 3.5 & b & 12.7 & c & 40.8 & C & 13.8 & $\mathrm{a}$ \\
\hline 9 & x RBM & 73.5 & def & 2.8 & $\mathrm{dD}$ & 12.3 & bc & 35.8 & bc & 12.7 & $\mathrm{a}$ \\
\hline 10 & $\begin{array}{l}\text { VIMA } \\
\text { VIMA }\end{array}$ & 45.0 & a & 2.3 & ab & 10.7 & $a b$ & 17.5 & $\mathrm{a}$ & 8.3 & $\mathrm{a}$ \\
\hline 11 & $\begin{array}{l}\text { RBK } \\
\text { VIMA }\end{array}$ & 48.0 & $\mathrm{ab}$ & 1.8 & $\mathrm{a}$ & 11.8 & abc & 26.8 & abc & 8.4 & $\mathrm{a}$ \\
\hline 12 & RBM & 50.8 & $a b$ & 1.8 & $\mathrm{a}$ & 11.9 & abc & 27.5 & abc & 12.3 & $\mathrm{a}$ \\
\hline 13 & RBK & 84.5 & $\mathrm{f}$ & 3.5 & D & 10.9 & $a b c$ & 81.0 & d & 23.2 & $\mathrm{~b}$ \\
\hline 14 & RBM & 85.0 & $\mathrm{f}$ & 3.0 & $a b$ & 10.9 & $a b c$ & 76.0 & d & 23.0 & $\mathrm{~b}$ \\
\hline
\end{tabular}

Karakteristik populasi keturunan persilangan antar spesies kacang hijau dengan kacang uci ini berada diantara karakteristik kedua tetuanya. Perbedaan karakteristik yang menyolok dari kedua tetuanya yaitu jumlah polong per tanaman, tinggi tanaman, dan berat biji per tanaman. Tipe pertumbuhan kacang uci cenderung semideterminate dimana walaupun tanaman sudah berbunga pada kondisi tertentu 
tanaman akan terus tumbuh dan berkembang sehingga tanamannya menjadi lebih tinggi. Menurut Maesen dan Somaatmadja (1989), keunggulan dari kacang uci disamping ketahanan terhadap beberapa hama juga memunyai jumlah polong per tanaman yang banyak sehingga sangat potensial digunakan sebagai tetua untuk meningkatkan produksi. Jumlah polong per tanaman merupakan komponen hasil yang penting dan umumnya berkorelasi positif nyata dengan hasil atau berat biji kering per tanaman. Hal ini berarti bahwa dengan memperbaiki jumlah polong per tanaman akan secara tidak langsung akan mempengaruhi hasil. Keturunan hasil persilangan juga memiliki kecenderungan semi determinate pada kondisi-kondisi tertentu terutama kalau banyak tersedia air walaupun tingkatnya tidak sebesar kacang uci. Dengan tipe pertumbuhan yang cenderung semideterminate memungkinkan terjadinya peningkatan hasil yang dicerminkan oleh berat biji per tanaman karena tanaman akan terus menghasilkan polong yang berarti akan meningkatkan hasil. Karakteristik populasi keturunan hasil persilangan antar spesies cenderung berada diantara kedua karakteristik kedua tetua.

Pada Tabel 2 terlihat bahwa berdasarkan uji berjarak ganda Duncan pada taraf nyata $5 \%$ terdapat keragaman pengaruh antara faktor yang satu dengan yang lain. Untuk sifat jumlah polong, tinggi tanaman dan berat biji per tanaman, keturunan hasil persilangan berada diantara kedua tetuanya. Hal ini menunjukkan adanya perubahan sifat jumlah polong, tinggi tanaman dan berat biji per tanaman pada keturunan hasil persilangan akibat adanya penggabungan sifat dari kedua tetuanya. Kacang uci memiliki karakteristik tipe pertumbuhan semi determinit, jumlah polongnya 
banyak yang berbeda dengan sifat kacang hijau. Untuk sifat lain seperti jumlah cabang kacang uci hampir sama dengan kacang hijau.

Berat biji per tanaman kacang uci lebih tinggi tetapi kanopinya lebih luas sehingga membutuhkan jarak tanam yang lebih luas. Untuk sifat- sifat yang lainnya polanya tidak teratur karena sifat-sifat tersebut tidak menunjukkan karakteristik yang kontras antara kedua tetua yaitu kacang hijau dan kacang uci sehingga perubahan sifat pada keturunannya sulit diketahui polanya.

Tabel 3. Keragaman Genetik, Keragaman Fenotipik, Nilai Duga Heritabilitas Arti Luas pada Semua Peubah yang Diamati

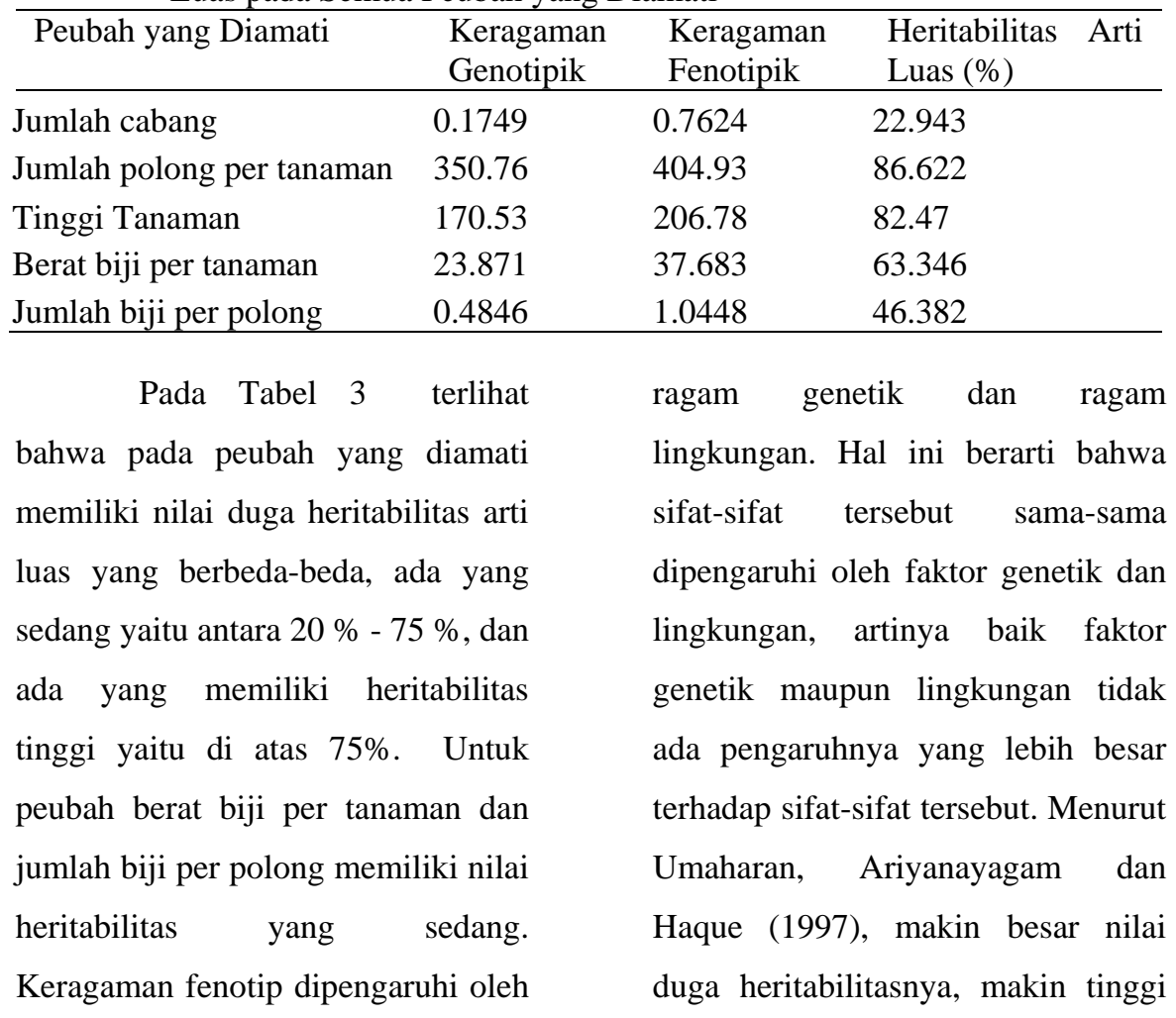


pengaruh faktor genetiknya dan sebaliknya, makin rendah nilai heritabilitasnya, makin besar pengaruh faktor lingkungannya. Untuk sifat jumlah polong menunjukkan nilai duga heritabilitas arti luas yang tinggi. Sifat ini sangat dipengaruhi oleh faktor genetik, kurang dipengaruhi oleh faktor lingkungan. Perubahan lokasi atau musim tanam tidak banyak membawa perubahan pada sifat tersebut. Sifat-sifat keturunan memiliki banyak kemiripan dengan sifat-sifat tetuanya. Terdapat pengaruh yang dominan oleh faktor genetik pada sifat ini. Hal ini juga menunjukkan indikasi bahwa gen pengendali sifat ini tidak banyak dan biasanya ada gen mayor yaitu gen yang menentukan sifat.

\section{KESIMPULAN DAN SARAN}

Berdasarkan data hasil dan pembahasan dapat disimpulkan :

1. Terjadi perbaikan daya hasil dan ketahanan kacang hijau terhadap hama kumbang bubuk pada populasi hasil persilangan dengan kacang uci.

2. Tingkat daya silang antara varietas yang satu dengan yang lainnya berbeda. Varietas Manyar dan Sampeong memiliki daya silang lebih tinggi terhadap kacang uci dibandingkan dengan varietas Vima dan Merak,

3. Karakteristik populasi keturunan hasil persilangan berada diantara kedua tetuanya.

Berdasarkan hasil dari penelitian ini disarankan bahwa galur-galur hasil persilangan antar spesies kacang hijau dan kacang uci perlu dilakukan pengujian-pengujian sifat yang lain selain daya hasil dan ketahanan terhadap hama kumbang 
bubuk terutama ketahanan terhadap

hama thrip yang banyak menyerang kacang hijau.

\section{UCAPAN TERIMA KASIH}

Penulis menyampaikan

ucapan terima kasih kepada Direktur

Jenderal Pendidikan Tinggi,

Kementerian Pendidikan Nasional

yang telah membantu pendanaan

pada penelitian ini. Kepala Balai
Penelitian Tanaman Kacangkacangan dan Umbi-umbian Malang yang telah membantu penyediaan benih dan pustaka. Bapak Ketua dan Laboran Laboratorium Produksi Fakultas Pertanian Universitas Mataram yang telah membantu penyediaan alat-alat penelitian. Bapak Ketua Laboratorium Kimia Analitik dan semua pihak yang telah membantu dalam penelitian ini. 


\section{DAFTAR PUSTAKA}

Arshad, M., M. Aslam, and M. Irshad. 2009. Genetic variability and character association among morphological traits of mungbean, Vigna radiata L. wilczek genotypes. J. Agric. Res. Vol. 47(2): 121-126

Badan Pusat Statistik. 2009. Luas panen, produktivitas dan produksi kacang hijau menurut provinsi. Badan Pusat Statistik Republik Indonesia, http://www.bps.go.id.[20 Februari 2010]

Bharathi, A, K.S.V. Selvaraj, P. Veerabadhiran, and B.S. Lakshmi. 2006. Crossability barriers in mungbean (Vigna radiata L. Wilczek): with its wild relatives. Indian J. Crop Science, Vol. 1(1-2): 120-124

Chen, N.C., L.R.Baker, and S..Honma. 1983. Interspecific crossability among four species of vigna food legumes. Euphytica Vol. 32: 925-937

Chiang, H.S. and N.S. Talekar. 1980. Identification of sources of resistance to beanfly and two other gromyzid flies in soybean and mungbean. J. Econ. Entomol. 73: 197-199

Cupka, T.B. and L.H. Edwards. 1986. A new technique for crossing mungbeans. Crop Sci 26:830-831

Gomathinayagam, P., S.G. Ram, R. Rathaswamy and N.M. Ramaswamy. 1998. Interspecific hybridization between Vigna unguiculata (L.) Walp. and V. vexillata (L.) A.Rich. through in vitro embryo culture. Euphytica 102: 203-209.

Gopinathan, M.C. and C.R. Babu. 1986. Meiotic studies of the F1 hybrid between rice bean (Vigna umbellata) and its wild relative V. minima. Genetica Vol. 71(2): $115-117$

Gopinathan, M.C., C. R. Babu and K. R. Shivanna. 1986. Interspecific hybridization between rice bean (Vigna umbellata) and its wild relative (V. minima): Fertility-sterility relationships. Euphytica, Vol. 35(3): 10171022.

Hadley, H.H. and S.J. Openshaw. 1980. Interspecific and intergeneric hybridization. p. 133-160. In: W.R. Fehr and H.H. Hadley (eds.), Hybridization of crop plants. American Society of Agronomy and Crop Science Society of America, Wisconsin, USA.

Khattak, G.S.S., M. Ashraf and M. S. Khan. 2004. Assessment of genetic variation for yield and yield components in mungbean 